\title{
Fitness of two phenotypes of Harmonia axyridis (Coleoptera: Coccinellidae)
}

\author{
Antonio O. SOARES ${ }^{1}$, Daniel CODERRE ${ }^{2}$ and HenRIQue SCHANDERL ${ }^{1}$ \\ ${ }^{1}$ Department of Biology, University of Azores, Rua Mãe de Deus, 58, 9501-801 Ponta Delgada, Portugal; e-mail: \\ onofre@notes.uac.pt \\ ${ }^{2}$ Département des Sciences Biologiques, Université du Québec à Montréal, C.P. 8888 Succ. Centre-ville, Montreal, Canada H3C \\ 3P8; e-mail: coderre.daniel@uqam.ca
}

Key words. Harmonia axyridis, phenotype, aulica, nigra, intraspecific variability, fitness, voracity, biomass, longevity, reproduction

\begin{abstract}
The coccinellid $H$. axyridis shows considerable intraspecific variability of elytral patterns. In this paper, we suggest that a genotype that confers a specific pattern of elytra could also confer other specific autecological attributes. The aim of this paper is to compare fitness parameters of two phenotypes (aulica and nigra). Aulica is a common morph characterized by two light red areas that nearly cover the whole elytra, leaving a narrow black border, whereas nigra is completely black; the latter is a rare morph that was naturally obtained from mass cultures. Intraspecific differences occur between $H$. axyridis phenotypes. The aulica phenotype is more voracious than nigra. Consumption rate of males is higher in aulica than in nigra, but there is no difference for females. Larval biomass of aulica is generally higher than that of nigra. The maximum body-weights reached by larval instars and adults are significantly higher for aulica. Aulica also has greater longevity and reproductive capacity. Only life stage duration of eggs and pre-pupae differ between the two phenotypes. Nigra shows lower fecundity and fertility. Our study showed that the strong differences in phenotype traits of the coccinellid $H$. axyridis could affect its fitness.
\end{abstract}

\section{INTRODUCTION}

Fitness can be defined as the measure of the relative performance of genotypes of a species and their contribution to future generations (Begon et al., 1990). The direct evaluation of fitness has rarely been performed (Hoffman, 1994). Most researchers generally measure fitness indirectly by using parameters such as body size, developmental time, fecundity and fertility.

In biological control, indirect measures of fitness are often used to evaluate the efficacy of a predator and its capacity population increase following field introduction. Performance may vary among phenotypes of the same species. In this study we compare five fitness parameters of two phenotypes of the coccinellid Harmonia axyridis Pallas.

H. axyridis is a Palaearctic species originating in the Far East. (Komai, 1956; Iablokoff-Khnzorian, 1982; Chapin \& Brou, 1991), that was introduced successfully in to North America (McClure, 1987; Chapin \& Brou, 1991; Day et al., 1994; Tedders \& Schaefer, 1994; Coderre et al., 1995; Dreistadt et al., 1995; Kidd \& Nalepa, 1995; Brown \& Miller, 1998), France (Ongagna et al., 1993) and the Azores islands (Schanderl et al., 1991; Schanderl \& Almeida, 1992).

H. axyridis is a highly polymorphic species and some phenotypes were previously considered as different species and genera (Komai, 1956). Phenotypes are classified in two groups, the succinea group, that have a light reddish or brownish ground colour and the melanic group that included the conspicua, spectabilis and aulica subgroups showing elytral patterns with melanic areas of different size and shape (Tan, 1946, 1949; Komai, 1956). Recently Schanderl (in prep.) described the nigra pheno- type, a new completely black phenotype, which was obtained in the laboratory.

H. axyridis shows a striking geographic variation in the relative frequency of elytral pattern phenotypes. Variations were generally related to geographical and seasonal factors (Kryltsov, 1956; Abbas \& Nakamura, 1985; Abbas et al., 1988; Osawa \& Nishida, 1992; Hodek \& Honěk, 1996). Precise factors determining geographical variation are, however, difficult to determine (Muggleton, 1978). Macrogeographical variations of Asian populations of $H$. axyridis were mostly related to climatic factors, whereas microgeographical variations were mostly related to food availability. Light and melanic phenotypes show different physiological adaptations to climatic conditions (Komai, 1956), whereas Komai \& Hosino (1951) found differences in the relative frequency of elytral pattern phenotypes among samples collected from different host plants supporting different aphid species. Seasonal variation in the proportion of dark and light forms in Japanese populations was also observed (Tan, 1949; Osawa \& Nishida, 1992). Osawa \& Nishida (1992) were able to demonstrate a significant increase of light phenotypes during spring and early summer. It seems that assortative mating can maintain the variation in morph proportion observed under natural conditions. Long-time changes in relative frequency of elytral pattern phenotypes were observed in the Suwa population, Japan. Komai (1956) supposed that this change was due to natural selection, probably in relation to the currently milder winters in Suwa.

Those observations suggest that polymorphism in $H$. axyridis can be an adaptive trait. We hypothesised that a (1) rare phenotype should show lower fitness than a more 
common phenotype, and (2) that a particular genotype that confers a specific coloration pattern could also confer other specific attributes, as stated by Lamana \& Miller (1995). We therefore predict that the rare and completely black nigra phenotype, should show a lower performance than the more common aulica phenotype, in which the confluent red areas occupy nearly the whole elytra, leaving a narrow black border on proximal and external margins.

\section{MATERIAL AND METHODS}

$H$. axyridis individuals of the aulica and nigra phenotypes came from mass rearing at $22 \pm 1{ }^{\circ} \mathrm{C}, 75 \pm 5 \% \mathrm{RH}$ and a photoperiod of $16 \mathrm{~L}: 8 \mathrm{D}$. Coccinellids were fed on a mixed diet of the aphids Aphis fabae Scopoli and Myzus persicae Sulzer, and eggs of Ephestia kuehniella Zeller. Field collected individuals were added regularly to avoid consanguinity. Aulica and nigra phenotypes occur naturally in our cultures. Before the experiment, we reared separately the nigra and aulica phenotypes in order to increase their number.

All experiments were performed at $20 \pm 1^{\circ} \mathrm{C}, 75 \pm 5 \% \mathrm{RH}$ and a photoperiod of $16 \mathrm{~L}: 8 \mathrm{D}$ under fluorescent lamps. Larval mortality was very low and did not differ between phenotypes tested. Developmental time, duration of feeding period, voracity and body weight of the aulica and nigra phenotypes were evaluated in $7 \mathrm{ml}$ Petri dishes ( $: 3 \mathrm{~cm}$, height $1 \mathrm{~cm}$ ). Individuals were fed with apterous $A$. fabae female aphids twice a day (09:00 and 17:00). The number of prey offered depended on the developmental stage: 15 individuals (09:00: 5, 17:00: 10), 30 $(10,20), 50(20,30), 80(30,50)$ and $80(30,50)$ for L1, L2, L3, L4 and adults, respectively. Aphid weight was evaluated in order to ensure that approximately the same aphid biomass was provided to all individuals of each treatment. Weight of prey provided and weight of predators were recorded twice a day (09:00 and 17:00) (10-4 mg Mettler AM50 analytical balance).

Developmental time was evaluated by observing 30 individuals of each phenotype twice a day (09:00 and 17:00) from egg to death of the adult. Duration of the feeding period of immature instars was also evaluated. Feeding period is defined as the time of active feeding.

Total and daily voracity were evaluated for larvae and adults. Male and female voracity was evaluated during the first eighteen days after emergence. A partly consumed or sucked aphid was considered predated. We defined total voracity as the number of aphids eaten during a given instar. Daily voracity (DV) was calculated during the feeding period by the following equation:

$$
\mathrm{DV}=\mathrm{na} / \mathrm{fp}
$$

where "na" is the number of aphids predated and "fp" the duration of the feeding period (in days).

Consumption rate (CR) of 24 h-old-larvae and 24 h-old-adults were evaluated by considering the number of aphids eaten on the second day after moulting (SDV) in relation to the first day weight of larvae or adults $\left(\mathrm{W}_{\mathrm{i}}\right)$ :

$$
\mathrm{CR}=\mathrm{SDV} / \mathrm{W}_{\mathrm{i}}
$$

First day weight $\left(\mathrm{W}_{\mathrm{i}}\right)$, maximal weight $\left(\mathrm{W}_{\mathrm{m}}\right)$ and body-weight increase $\left(W_{m}-W_{i}\right)$ were calculated for each instar and for the first eighteen days of adult development after emergence. The initial weights of pupae were also compared.

In order to evaluate adult longevity and reproduction parameters, we sexed and paired 40 individuals of each phenotype Each couple was isolated in a $60 \mathrm{ml}$ Petri dish $(\varnothing: 5 \mathrm{~cm}$, height: $3 \mathrm{~cm}$ ). A surplus of prey (A. fabae) was always provided. Egg clusters were removed from Petri dishes and observed twice a day. Fecundity and fertility (including sibling cannibalism) were compared both for the first fifteen days and for the total lifetime of females after sexual maturation.

Developmental time, duration of feeding period, voracity, initial and maximal weight, longevity, fecundity and fertility of the aulica and nigra phenotypes were compared by one-way ANOVA (Abacus Concepts, Super ANOVA version 1.1 for MacIntosh, 1989).

\section{RESULTS}

Total pre-adult developmental time did not differ between the aulica and nigra phenotypes. We only observed a shorter developmental time for anlica eggs and a shorter pre-pupal developmental time for nigra (Table 1).

Total duration of feeding period did not differ significantly between the aulica and nigra phenotypes (Table 1). However, second and third instars of aulica fed on aphids for a significantly longer time than nigra (Table 1). Total voracity, average daily voracity and 24 h-oldcoccinellid voracity of first, second, third, fourth instars as well as adult males and females were significantly higher for aulica than for nigra (Table 2). Consumption rate of pre-imaginal and adult stages was also significantly higher for the aulica phenotype, except for adult females (Table 3 ).

First day weight and maximal weight of the first instar did not differ for aulica and nigra phenotypes. However, first day weight and maximal weight of second, third and fourth instars were significantly higher for aulica. No significant difference in body weight increase was observed for first, second, third or fourth instars. Pupal body weight and first day weight and maximal weight of adult females and males were significantly higher for aulica. However, no significant differences in the body weight increase of adults, males or females, were found (Table 4).

The longevity and total and daily fecundity of the aulica phenotype were higher than those for nigra. The same trend was observed for both total and daily fecundity during the first fifteen days after sexual maturation. Aulica egg fertility was higher than nigra for both total lifetime and for the first fifteen days after sexual maturation. Hatching percentage of nigra eggs was very low $(4,5 \%)$ (Table 5).

\section{DISCUSSION}

Biological control programs generally focus on the selection of the best parasitoid or predator species to be introduced, based on criteria related to their capacity to have a substantial impact on the pest population (Waage $\&$ Mills, 1992). However, the selection of the fittest phenotype of a selected species is rarely done. The selection of the best phenotype will depend on the biological control strategy used. Indirect fitness parameters that will favour population establishment and stabilisation will be used in classical programs of biological control, whereas short-term efficacy will be favoured in inundative biological control programs. Our results indicate that aulica individuals are heavier and more voracious than nigra. 
TABLE 1. Developmental time and duration of feeding period of pre-adult stages of aulica and nigra phenotypes of Harmonia axyridis.

\begin{tabular}{|c|c|c|c|c|c|c|c|}
\hline \multirow[t]{2}{*}{ Stage } & \multicolumn{3}{|c|}{ Developmental time (days \pm se) } & & \multicolumn{3}{|c|}{ Duration of feeding period (days \pm se) } \\
\hline & aulica & nigra & & & aulica & nigra & \\
\hline Egg & $4.4 \pm 0.04 \mathrm{a}^{*}$ & $4.8 \pm 0.12 b$ & $\mathrm{~F}=14.3, \mathrm{df}=1,29, \mathrm{P}=0.0007$ & & 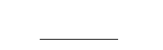 & 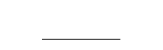 & \\
\hline First instar & $3.1 \pm 0.07 \mathrm{a}$ & $3.2 \pm 0.08 \mathrm{a}$ & $\mathrm{F}=0.352, \mathrm{df}=1,71, \mathrm{P}=0.554$ & & $2.6 \pm 0.08 \mathrm{a}$ & $2.8 \pm 0.09 \mathrm{a}$ & $\mathrm{F}=0.952, \mathrm{df}=1,71, \mathrm{P}=0.332$ \\
\hline Second instar & $2.3 \pm 0.05 \mathrm{a}$ & $2.1 \pm 0.05 \mathrm{a}$ & $\mathrm{F}=3.024, \mathrm{df}=1,71, \mathrm{P}=0.086$ & & $2.1 \pm 0.06 \mathrm{a}$ & $2.1 \pm 0.06 \mathrm{a}$ & $\mathrm{F}=5.44, \mathrm{df}=1,71, \mathrm{P}=0.022$ \\
\hline Third instar & $2.6 \pm 006 \mathrm{a}$ & $2.5 \pm 0.28 \mathrm{a}$ & $\mathrm{F}=0.817 \mathrm{df}=1,71, \mathrm{P}=0.369$ & & $2.3 \pm 0.06 \mathrm{a}$ & $1.9 \pm 0.07 \mathrm{~b}$ & $\mathrm{~F}=23.4, \mathrm{df}=1,71, \mathrm{P} \leq 0.0001$ \\
\hline Fourth instar & $4.7 \pm 0.10 \mathrm{a}$ & $4.7 \pm 0.10 \mathrm{a}$ & $\mathrm{F}=0.047 \mathrm{df}=1,71, \mathrm{P}=0.829$ & & $4.0 \pm 0.09 \mathrm{a}$ & $4.0 \pm 0.10 \mathrm{a}$ & $\mathrm{F}=0.053, \mathrm{df}=1,71, \mathrm{P}=0.818$ \\
\hline Pre-pupa & $1.2 \pm 0.04 \mathrm{a}$ & $1.0 \pm 0.03 \mathrm{~b}$ & $\mathrm{~F}=14.7, \mathrm{df}=1,70, \mathrm{P}=0.0003$ & & 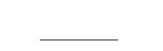 & 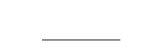 & \\
\hline Pupa & $6.3 \pm 0.19 \mathrm{a}$ & $6.2 \pm 0.07 \mathrm{a}$ & $\mathrm{F}=0.164, \mathrm{df}=1,70, \mathrm{P}=0.687$ & & 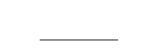 & 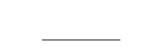 & \\
\hline Larva and pupa & $20.5 \pm 0.36 \mathrm{a}$ & $20.0 \pm 0.21 \mathrm{a}$ & $\mathrm{F}=1.048, \mathrm{df}=1,70, \mathrm{P}=0.309$ & $\begin{array}{l}\text { Total larval } \\
\text { development }\end{array}$ & $11.2 \pm 1.5 \mathrm{a}$ & $10.8 \pm 1.0 \mathrm{a}$ & $\mathrm{F}=1.647, \mathrm{df}=1,71, \mathrm{P}=0.203$ \\
\hline
\end{tabular}

* Different letters indicate significant differences (Fisher's Protected LSD test; $\mathrm{p}<0.05$ ).

TABLE 2. Total and daily voracity of larvae and a 24-hour-old adult voracity of aulica and nigra phenotypes of Harmonia axyridis.

\begin{tabular}{|c|c|c|c|c|c|c|c|c|c|}
\hline \multirow[b]{3}{*}{ Instar/sex } & \multicolumn{9}{|c|}{ Number of aphids consumed $( \pm \mathrm{se})$} \\
\hline & \multicolumn{2}{|c|}{ Total } & & \multicolumn{2}{|c|}{ Daily } & & \multicolumn{2}{|c|}{ For a 24-hour-old adult } & \\
\hline & aulica & nigra & & aulica & nigra & & aulica & nigra & \\
\hline First & $10.6 \pm 0.47 \mathrm{a}^{*}$ & $6.9 \pm 0.39 \mathrm{~b}$ & $\begin{array}{c}\mathrm{F}=32.7, \mathrm{df}=1,71 \\
\mathbf{P} \leq 0.0001\end{array}$ & $3.9 \pm 0.14 \mathrm{a}$ & $2.4 \pm 0.12 \mathrm{~b}$ & $\begin{array}{c}F=55.3, \mathrm{df}=1,71, \\
\mathrm{P} \leq 0.0001\end{array}$ & $4.2 \pm 0.25 \mathrm{a}$ & $3.0 \pm 0.19 \mathrm{~b}$ & $\begin{array}{c}F=13.2, \mathrm{df}=1,71 \\
\mathrm{P}=0.0005\end{array}$ \\
\hline Second & $31.5 \pm 1.98 \mathrm{a}$ & $9.4 \pm 0.49 \mathrm{~b}$ & $\begin{array}{c}\mathrm{F}=88.42, \mathrm{df}=1,71 \\
\mathrm{P} \leq 0.0001\end{array}$ & $14.7 \pm 0.82 \mathrm{a}$ & $5.1 \pm 0.28 \mathrm{~b}$ & $\begin{array}{c}F=92.6, d f=1,71 \\
P \leq 0.0001\end{array}$ & $13.7 \pm 0.90 \mathrm{a}$ & $3.3 \pm 0.34 \mathrm{~b}$ & $\begin{array}{c}\mathbf{F}=90.46, \mathrm{df}=1,71, \\
\mathbf{P} \leq 0.0001\end{array}$ \\
\hline Third & $56.3 \pm 1.97 \mathrm{a}$ & $26.1 \pm 1.40 \mathrm{~b}$ & $\begin{array}{c}F=135.06, \mathrm{df}=1,71, \\
P \leq 0.0001\end{array}$ & $24.2 \pm 0.86 \mathrm{a}$ & $14.0 \pm 0.76 \mathrm{~b}$ & $\begin{array}{c}\mathrm{F}=71.35, \mathrm{df}=1,71 \\
\mathrm{P} \leq 0.0001\end{array}$ & $25.4 \pm 2.50 \mathrm{a}$ & $13.1 \pm 0.85 \mathrm{~b}$ & $\begin{array}{c}\mathrm{F}=16.67, \mathrm{df}=1,71, \\
\mathrm{P} \leq 0.0001\end{array}$ \\
\hline Fourth & $190.3 \pm 4.48 \mathrm{a}$ & $118.3 \pm 3.81 \mathrm{~b}$ & $\begin{array}{c}\mathrm{F}=136.7, \mathrm{df}=1,71 \\
\mathrm{P} \leq 0.0001\end{array}$ & $47.6 \pm 1.23 \mathrm{a}$ & $29.5 \pm 1.28 \mathrm{~b}$ & $\begin{array}{c}\mathrm{F}=100.14, \mathrm{df}=1,71, \\
\mathrm{P} \leq 0.0001\end{array}$ & $56.5 \pm 1.39 \mathrm{a}$ & $35.8 \pm 1.90 \mathrm{~b}$ & $\begin{array}{c}\mathrm{F}=81.2, \mathrm{df}=1,71 \\
\mathrm{P} \leq 0.0001\end{array}$ \\
\hline Adult female & $769.3 \pm 12.7 \mathrm{a}^{* *}$ & $624.1 \pm 10.7 \mathrm{~b}$ & $\begin{array}{c}\mathrm{F}=72.4, \mathrm{df}=1,31 \\
\mathrm{P} \leq 0.0001\end{array}$ & $43.2 \pm 0.49 \mathrm{a}$ & $33.5 \pm 0.8 b$ & $\begin{array}{c}\mathrm{F}=101.5, \mathrm{df}=1,31 \\
\mathrm{P} \leq 0.0001\end{array}$ & $40.0 \pm 2.13 \mathrm{a}$ & $31.9 \pm 1.44 \mathrm{~b}$ & $\begin{array}{c}\mathrm{F}=9.15, \mathrm{df}=1,31 \\
\mathrm{P}=0.005\end{array}$ \\
\hline Adult male & $775.8 \pm 19.6 \mathrm{a}^{* *}$ & $530.2 \pm 15.7 \mathrm{~b}$ & $\begin{array}{c}\mathrm{F}=93.2, \mathrm{df}=1,27 \\
\mathrm{P} \leq 0.0001\end{array}$ & $43.1 \pm 1.09 \mathrm{a}$ & $29.4 \pm 0.8 \mathrm{~b}$ & $\begin{array}{c}\mathrm{F}=93.2, \mathrm{df}=1,27 \\
\mathrm{P} \leq 0.0001\end{array}$ & $36.2 \pm 1.66 \mathrm{a}$ & $23.0 \pm 1.88 \mathrm{~b}$ & $\begin{array}{c}F=27.4, d f=1,27 \\
P \leq 0.0001\end{array}$ \\
\hline
\end{tabular}

* Different letters indicate significant differences (Fisher's Protected LSD test; $\mathrm{p}<0.05$ ).

** Values measured during eighteen days after the adult emergence. 
TABLE 3. Consumption rate of aulica and nigra phenotypes of Harmonia axyridis.

\begin{tabular}{|c|c|c|c|}
\hline \multicolumn{4}{|c|}{ Consumption rate $^{1)}$} \\
\hline & \multicolumn{3}{|c|}{ number of aphids \pm se per mg of coccinellid } \\
\hline Instar /sex & aulica & nigra & \\
\hline First & $4.3 \pm 0.25 \mathrm{a}^{2)}$ & $3.5 \pm 0.29 \mathrm{~b}^{2)}$ & $\begin{array}{c}\mathrm{F}=4.5, \mathrm{df}=1,71, \\
\mathrm{P}=0.037\end{array}$ \\
\hline Second & $4.2 \pm 0.31 \mathrm{a}$ & $1.1 \pm 0.11 \mathrm{~b}$ & $\begin{array}{c}\mathbf{F}=65.6, \mathrm{df}=1,71, \\
\mathbf{P} \leq 0.0001\end{array}$ \\
\hline Third & $2.1 \pm 0.21 \mathrm{a}$ & $1.2 \pm 0.08 \mathrm{~b}$ & $\begin{array}{c}F=11.5, \mathrm{df}=1,71, \\
\mathbf{P}=0.001\end{array}$ \\
\hline Fourth & $1.1 \pm 0.02 \mathrm{a}$ & $0.8 \pm 0.03 \mathrm{~b}$ & $\begin{array}{c}\mathbf{F}=57.9, \mathrm{df}=1,71, \\
\mathbf{P} \leq 0.0001\end{array}$ \\
\hline Adult female ${ }^{3)}$ & $1.07 \pm 0.05 \mathrm{a}$ & $0.99 \pm 0.6 \mathrm{a}$ & $\mathbf{F}=1.07, \mathrm{df}=1,31$, \\
\hline Adult male ${ }^{3)}$ & $1.1 \pm 0.05 \mathrm{a}$ & $0.86 \pm 0.06 \mathrm{~b}$ & $\begin{array}{c}\mathrm{F}=8.83, \mathrm{df}=1,27, \\
\mathrm{P}=0.006\end{array}$ \\
\hline
\end{tabular}

1) Number of aphids eaten on the second day after moult in relation to the weight of the coccinellid.

2) Different letters indicate significant differences (Fisher's Protected LSD test, $\mathrm{p}<0.05$ ).

3) Values measured during eighteen days after the adult emergence.

They also have a higher longevity and better reproductive performance, indicating that the aulica phenotype should be preferred in both strategies in temperate climates.

Egg and pupal developmental times depend mainly on metabolic rate, but for larvae it could also depend on the access to prey (Honěk \& Kocourek, 1990). The duration of embryonic development differs among coccinellid species and is related to the rate of development and lower developmental threshold for Coccinella californica Mannerheim, C. trifasciata Linnaeus, C. undecimpunctata Linnaeus, C. septempunctata Linnaeus, Cycloneda polita Casey, Adalia bipunctata (Linnaeus) and Hippodamia convergens Guerin (Frazer \& McGregor, 1982). Faster embryonic development and consequently earlier larval hatching give two advantages to the first instar: a lower probability of cannibalism (Mills, 1982) or intraguild predation (Lucas et al., 1998), and earlier access to prey colonies. According to our results the aulica phenotype should therefore have an adaptive advantage on the nigra phenotype.

However we found no differences in larval developmental time between the two phenotypes. Similar results were obtained for Calvia quatuordecimguttata (Linnaeus), where no significant differences in preimaginal developmental time were observed among its three phenotypes (Lamana \& Miller, 1995). Those results suggest that larval developmental time, if fixed genetically, does not differ between the phenotypes or is not genetically fixed and only varies in relation with food consumption and abiotic conditions (e.g. temperature).

Temperature determines also the longevity of poikilothermic species. Coccinellid lifetime generally decreases with the increase of temperature. This effect was noticed for Coccinella novemnotata Herbst (McMullen, 1967), C. maculata (Wright \& Laing, 1978) and Olla v-nigrum (Mulsant) (Kreiter \& Iperti, 1984). Despite the fact that temperature was fixed at $20^{\circ} \mathrm{C}$ for both phenotypes in our experiment, nigra phenotype was found to have a shorter adult longevity. For polymorphic species like $H$. axyridis, the degree of elytral melanization can also be an important factor affecting longevity. Melanic forms can reach a higher body temperature than non-melanic forms (De Jong et al., 1996). Consequently they can reach higher metabolic rate and biological activity (Digby, 1955; Lusis, 1961; Dixon, 1972; Benham et al., 1974; Muggleton et al., 1975; Willmer \& Unwin, 1981; Brakefield \& Willmer, 1985; Stewart \& Dixon, 1989; De Jong et al., 1996).

Nigra larvae need a lower food biomass to complete their pre-imaginal development than aulica. This suggests that nigra phenotype could be better adapted to food scarcity. Larval voracity depends on growth rate and food assimilation efficiency (Hodek \& Honěk, 1996). Since larval body-weight increase did not differ between the two phenotypes and because consumption rate of aulica was higher than that of nigra, it suggests that the two phenotypes differ in their food assimilation efficiency or in their metabolic rate. Therefore the aulica phenotype should have lower food assimilation efficiency or higher maintenance or searching costs.

Aulica is heavier and more voracious than the nigra phenotype. This should give an advantage to aulica as it can provide more resources for egg production than nigra. This was also demonstrated in other coccinellids by Stewart et al. (1991a; b), Ferran et al. (1984) and Honěk (1993). Every species has genetically fixed fecundity and egg size that are conditioned by food availability and environmental conditions. If food supply is limited, coccinellids could decrease their fecundity but will maintain the egg size (Hodek \& Honěk, 1996). The absence of significant differences in initial weight of first instars and lower fecundity of the nigra phenotype suggest that egg size is genetically fixed and does not depend on female size. As a result, neonate larvae weight should not differ between nigra and aulica, giving an equal chance to both phenotypes to survive and find food resource.

Our study showed great differences in phenotype traits of the coccinellid $H$. axyridis that could affect their fitness. Phenotypes such as nigra, that have low fitness, are therefore expected to be very rare. There are several possible evolutionary responses to environmental heterogeneity, including genetic polymorphism, ecological generalisation, habitat selection and phenotypic plasticity. Thus, we could hypothesize that the fitness of nigra phenotype could possibly change in conditions different from those tested here. Additional experiments at other temperatures should be done. If the phenotype conferring maximum fitness changes as the environmental conditions alter, no single optimal phenotype exists (Buskirk et al., 1997). Polymorphism should persist only when different genotypes are selectively favoured in varying parts of the environment or at different times (Ricklefs, 1990). Our results suggest that $H$. axyridis has adopted a genetic polymorphism strategy (Futuyma, 1998), where fitness enhancement in differing phenotypes has occurred, 
TABLE 4. Biomass features of aulica and nigra phenotypes of Harmonia axyridis.

\begin{tabular}{|c|c|c|c|c|c|c|c|c|c|}
\hline \multirow[b]{3}{*}{ Instar / sex } & \multicolumn{9}{|c|}{ Biomass features (mg $\pm \mathrm{se})$} \\
\hline & \multicolumn{2}{|c|}{ First day weight } & & \multicolumn{2}{|c|}{ Maximal weight } & & \multicolumn{2}{|c|}{ Body-weight increase } & \\
\hline & aulica & nigra & & aulica & nigra & & aulica & nigra & \\
\hline First & $0.1 \pm 0.00 \mathrm{a}^{*}$ & $0.1 \pm 0.01 \mathrm{a}$ & $\begin{array}{c}\mathrm{F}=0.25, \mathrm{df}=1,71 \\
\mathrm{P}=0.617\end{array}$ & $0.9 \pm 0.06 \mathrm{a}$ & $0.9 \pm 0.02 \mathrm{a}$ & $\begin{array}{c}\mathrm{F}=0.23, \mathrm{df}=1,71 \\
\mathrm{P}=0.628\end{array}$ & $0.8 \pm 0.06 \mathrm{a}$ & $0.8 \pm 0,03 \mathrm{a}$ & $\begin{array}{c}\mathrm{F}=0.12, \mathrm{df}=1,71, \\
\mathrm{P}=0.728\end{array}$ \\
\hline Second & $1.2 \pm 0.00 \mathrm{a}$ & $0.9 \pm 0.05 \mathrm{~b}$ & $\begin{array}{c}\mathrm{F}=22.06, \mathrm{df}=1,71, \\
\mathrm{P} \leq 0.0001\end{array}$ & $3.3 \pm 0.08 \mathrm{a}$ & $2.7 \pm 0.06 \mathrm{~b}$ & $\mathrm{~F}=\underset{\mathrm{P} \leq 0.0001}{24.5, \mathrm{df}=1,71}$ & $2.0 \pm 0.09 \mathrm{a}$ & $1.8 \pm 0,07 \mathrm{a}$ & $\begin{array}{c}\mathrm{F}=2.43, \mathrm{df}=1,71, \\
\mathrm{P}=0.122\end{array}$ \\
\hline Third & $3.6 \pm 0.12 \mathrm{a}$ & $2.8 \pm 0.17 \mathrm{~b}$ & $\begin{array}{c}\mathrm{F}=16.5, \mathrm{df}=1,71 \\
\mathrm{P} \leq 0.0001\end{array}$ & $11.7 \pm 0.18 \mathrm{a}$ & $10.4 \pm 0.25 \mathrm{~b}$ & $\begin{array}{c}F=19.8, d f=1,71 \\
P \leq 0.0001\end{array}$ & $8.1 \pm 0.21 \mathrm{a}$ & $7.6 \pm 0.25 \mathrm{a}$ & $\mathrm{F}=2.29, \mathrm{df}=1,71$, \\
\hline Fourth & $14.8 \pm 0.62 \mathrm{a}$ & $11.1 \pm 0.42 \mathrm{~b}$ & $\begin{array}{c}\mathrm{F}=16.5, \mathrm{df}=1,71, \\
\mathrm{P} \leq 0.0001\end{array}$ & $48.6 \pm 0.76 \mathrm{a}$ & $42.4 \pm 0.76 \mathrm{~b}$ & $\mathrm{~F}=\underset{\mathrm{P} \leq 0.0001}{24.8, \mathrm{df}=1,71,}$ & $33.0 \pm 1.02 \mathrm{a}$ & $31.2 \pm 0.91 \mathrm{a}$ & $\begin{array}{c}F=1.55, d f=1,71, \\
P=0.217\end{array}$ \\
\hline Pupa & $39.5 \pm 0.64 \mathrm{a}$ & $35.5 \pm 0.80 \mathrm{~b}$ & $\begin{array}{c}\mathrm{F}=15.7, \mathrm{df}=1,71, \\
\mathrm{P}=0.0002\end{array}$ & & & & & & \\
\hline Adult female & $36.5 \pm 0.70 \mathrm{a}^{* *}$ & $30.6 \pm 1.28 \mathrm{~b}$ & $\begin{array}{c}\mathrm{F}=17.9, \mathrm{df}=1,31, \\
P=0.0002\end{array}$ & $49.5 \pm 0.93 \mathrm{a}$ & $43.9 \pm 1.31 \mathrm{~b}$ & $\begin{array}{c}\mathrm{F}=12.4, \mathrm{df}=1,31 \\
\mathrm{P}=0.0013\end{array}$ & $13.0 \pm 0.64 \mathrm{a}$ & $15.1 \pm 2,17 \mathrm{a}$ & $\begin{array}{c}F=1.03, \mathrm{df}=1,31, \\
\mathrm{P}=0.316\end{array}$ \\
\hline Adult male & $31.8 \pm 0.60 \mathrm{a}^{* *}$ & $27.0 \pm 0.78 \mathrm{~b}$ & $\begin{array}{c}\mathrm{F}=24.1, \mathrm{df}=1,27 \\
\mathrm{P} \leq 0.0001\end{array}$ & $40.1 \pm 1.15 \mathrm{a}$ & $33.5 \pm 0.84 \mathrm{~b}$ & $\begin{array}{c}F=20.9, d f=1,27 \\
P \leq 0.0001\end{array}$ & $8.2 \pm 0.83 \mathrm{a}$ & $6.4 \pm 0,51 \mathrm{a}$ & $\mathrm{F}=3.27, \mathrm{df}=1,27$, \\
\hline
\end{tabular}

* Different letters indicate significant differences (Fisher's Protected LSD test; $\mathrm{p}<0.05$ ).

** Values measured during eighteen days after the adult emergence. 
TABLE 5. Longevity and reproductive capacity of aulica and nigra phenotypes of Harmonia axyridis.

\begin{tabular}{lccc}
\hline & \multicolumn{2}{c}{ Longevity and reproductive capacity } & \\
\cline { 2 - 3 } & aulica & nigra & \\
\hline Longevity & $86.8 \pm 8.69 \mathrm{a}^{*}$ & $59.5 \pm 6.63 \mathrm{~b}$ & $\mathrm{~F}=6.42, \mathrm{df}=1,42, \mathrm{P}=0.015$ \\
Fecundity & & & \\
$\quad$ Total & $1840.5 \pm 214.8 \mathrm{a}$ & $774.6 \pm 95.9 \mathrm{~b}$ & $\mathrm{~F}=20.51, \mathrm{df}=1,38, \mathrm{P}=0.0003$ \\
$\quad$ Daily & $23.5 \pm 1.2 \mathrm{a}$ & $14.9 \pm 1.1 \mathrm{~b}$ & $\mathrm{~F}=26.67, \mathrm{df}=1,38, \mathrm{P} \leq 0.0001$ \\
$\begin{array}{l}\text { Fecundity (during } 15 \text { days after oviposi- } \\
\text { tion onset) }\end{array}$ & & \\
$\quad$ Total & $472.5 \pm 26.5 \mathrm{a}$ & $329.3 \pm 21.8 \mathrm{~b}$ & $\mathrm{~F}=17.3, \mathrm{df}=1,38, \mathrm{P}=0.0002$ \\
$\quad$ Daily & $31.5 \pm 1.7 \mathrm{a}$ & $21.9 \pm 1.4 \mathrm{~b}$ & $\mathrm{~F}=17.3, \mathrm{df}=1,38, \mathrm{P}=0.0002$ \\
Fertility (including sibling cannibalism) & $59.6 \pm 15.1 \mathrm{a}$ & $18.7 \pm 18.9 \mathrm{~b}$ & $\mathrm{~F}=56.7, \mathrm{df}=1,38, \mathrm{P} \leq 0.0001$ \\
$\quad \begin{array}{l}\text { Total } \\
\quad \text { During } 15 \text { days after oviposition onset }\end{array}$ & $54.8 \pm 6.3 \mathrm{a}$ & $20.8 \pm 5.4 \mathrm{~b}$ & $\mathrm{~F}=16.08, \mathrm{df}=1,38, \mathrm{P}=0.0004$ \\
$\begin{array}{l}\text { Percentage of hatching (during } 15 \text { days } \\
\text { after oviposition onset) }\end{array}$ & $54.0 \pm 4.3 \mathrm{a}$ & $4.5 \pm 1.5 \mathrm{~b}$ & $\mathrm{~F}=117.1, \mathrm{df}=1,38, \mathrm{P} \leq 0.0001$ \\
\hline
\end{tabular}

* Different letters indicate significant differences (Fisher's Protected LSD test; $p<0.05$ ).

resulting in an increased tolerance of a wide range of temperature conditions.

ACKNOWLEDGEMENTS. We thank Helena Figueredo and Roberto Resendes for technical assistance. This work was supported by Universidade dos Açores and a grant from Ministério da Eduçação de Portugal (PRODEP II) to A. O. Soares and by a grant from the Natural Science and Engineering Research Council of Canada (NSERC) to D. Coderre.

\section{REFERENCES}

Abacus Concepts 1989: Super Anova User's Guide, BrainPower. Abacus Concepts, Calabasas, CA.

AbBas I. \& NaKamura K. 1985: Variation of elytral spot patterns in a field population of lady beetle Epilachna aff. sparsa (Coleoptera: Coccinellidae) feeding on bitter cucumber in Sumatra. Sci. Rep. Kanazawa University 30: 27-32.

Abbas I., Nakamura K., Katakura H. \& SasaJ H. 1988: Geographical variation of elytral spot patterns in the ladybird Epilachna vigintiduopunctata (Coleoptera: Coccinellidae) in the province of Sumatrea Barat, Indonesia. Res. Popul. Ecol. 30: $43-56$.

Begon M., Harper J.L. \& Townsend C.R. 1990: Ecology: Individuals, Population and Communities. 2nd edition. Blackwell Scientific Publications, London. 945 pp.

Benham B.R., Lonsdale D. \& Muggleton J. 1974: Is polymorphism in twospot ladybird an example of non-industrial melanism? Nature 249: 179-180.

Brakefield P.M. \& Willmer P.G. 1985: The basis of thermalmelanism in the ladybird Adalia bipunctata: differences in reflectance and thermal properties between the morphs. Heredity 54: 9-14.

Brown M.W. \& MrLler S.S. 1998: Coccinellidae (Coleoptera) in apple orchards of eastern West Virginia and the impact of invasion by Harmonia axyridis. Entomol. News 109: 143-151

Buskirk J.V., Mccollum S.A. \& Werner E.E. 1997: Natural selection for environmentally induced phenotypes in tadpoles. Evolution 51: 1983-1992.

Chapin J.B. \& Brov V.A. 1991: Harmonia axyridis (Pallas), the third of the genus to be found in the United States (Coleoptera: Coccinellidae). Proc. Entomol. Soc. Wash. 93: 630-635.
Coderre D., Lucas E. \& Gagné I. 1995 : The occurrence of Harmonia axyridis Pallas (Coleoptera: Coccinellidae) in Canada. Can. Entomol. 127: 609-611.

Day W.H., Prokrym D.R., Ellis D.R. \& Chianese R.J. 1994: The known distribution of the predator Propylea quatuordecimpunctata (Coleoptera: Coccinellidae) in the United States, and thoughts on the origin of this species and five other exotic lady beetles in eastern North America. Entomol. News 105: 244-256.

De Jong P.W., Gusserloo S.W.S. \& Brakefield P.M. 1996: Differences in thermal balance, body temperature and activity between nonmelanic and melanic two-spot ladybird beetles (Adalia bipunctata) under controlled conditions. J. Exp. Biol. 199: 2655-2666.

DigBY P.S.B. 1955: Factors affecting the temperature excess of insects in sunshine. J. Exp. Biol. 32: 279-298.

DrXon A.F.G. 1972: Control and significance of the seasonal development of colour forms in the sycamore aphid, Drepanosiphum platanoides (Schr.). J. Anim. Ecol 41: 689-697.

Dreistadt S.H., Hagen K.S. \& Bezark L.G. 1995: Harmonia axyridis (Pallas) (Coleoptera: Coccinellidae), first western United States record for this Asiatic lady beetle. Pan-Pac. Entomol. 71: 135-136.

Ferran A., Cruz De Boelpaepe M.O., Schanderl H. \& LarROQUE M.M. 1984: Les aptitudes trophiques et reproductrices des femelles de Semiadalia undecimnotata (Col.: Coccinellidae). Entomophaga 29: 157-170.

Frazer B.D. \& MCGRegor R.R. 1992: Temperature-dependent survival and hatching rate of eggs of seven species of Coccinellidae. Can. Entomol. 124: 305-312.

Futurma D.J. 1998: Evolutionary Biology. 3rd edition. Sinauer Associates, Inc., Massachusetts, 763 pp.

HODEK I. \& HoNĚK A. 1996: Ecology of Coccinellidae. Kluwer Academic Publishers, Netherlands, $464 \mathrm{pp}$.

HoFFMAN A.A. 1994: Genetic analysis of territoriality of Drosophila melanogaster. In Boake C. (ed.): Quantitative Genetic Studies of Behavioral Evolution. Univ. Chicago Press, Chicago, $390 \mathrm{pp}$.

HoNĚK A. 1993: Intraspecific variation in body size and fecundity in insects: a general relationship. Oikos 66: 483-492.

HoNËK A. \& KoCOUREK F. 1990: Temperature and development time in insects: a general relationship between thermal constants. Zool. Jb. Syst. 117: 401-439. 
IABLOKOFF-Khnzorian S.M. 1982: Les Coccinelles; ColéoptèresCoccinellidae. Société Nouvelle des Éditions Boubée, Paris, France, $568 \mathrm{pp}$.

KidD K.A. \& NALEPA C.A. 1995: Distribution of Harmonia axyridis (Pallas) (Coleoptera: Coccinellidae) in North Carolina and Virginia. Proc. Entomol. Soc. Wash. 97: 729-731.

Komai T. 1956: Genetics of Ladybeetles. Advances in Genetics 8: $155-189$.

Komai T. \& Hosino Y. 1951: Contributions to the evolutionary genetics of the lady-beetle, Harmonia. II. Microgeographic variations. Genetics 36: 382-390.

KreITER S. \& IPERTI G. 1984: Étude des potentialitées biologiques et écologiques d'un prédateur aphidiphage Olla-vnigrum Muls. (Coleoptera: Coccinellidae) en vue de son introduction en France. 109 Congr. Nat. Soc. Savantes Dijon 1984 2: 275-282.

KRYLTSOV A.I. 1956: Geographical variability of lady-birds (Coleoptera: Coccinellidae) in north Kirghisia. Entomol. Obozr. 35: 771-781.

LAMANa M.L. \& MilleR J.F. 1995: Temperature-dependent development in polymorphic lady bettle, Calvia quatuordecimguttata (Coleoptera: Coccinellidae). Ann. Entomol. Soc. Am. 88: 785-790.

Lucas E., Coderre D. \& Brodeur J. 1998: Intraguild predation among aphid predators: characterization and influence of extraguild prey density. Ecology 79: 1084-1092.

Lusis J.J. 1961: On the biological meaning of colour polymorphism of ladybeetle Adalia bipunctata L. Latvijas Entomologs 4: 3-29.

MCClure M.S. 1987: Potential of the Asian predator, Harmonia axyridis Pallas (Coleoptera: Coccinellidae), to control Matsucoccus resinosae Bean and Godwin (Homoptera: Margarodidae) in the United States. Environ. Entomol. 16: 224-230.

McMulLEn R.D. 1967 : The effects of photoperiod, temperature, and food supply on rate of development and diapause in Coccinella novemnotata. Can. Entomol. 99: 578-586.

Mills N.J. 1982: Voracity, cannibalism and coccinellid predation. Ann. Appl. Biol. 101: 144-148.

MugGleton J. 1978: Selection against the melanic morphs of Adalia bipunctata L. (two-spot ladybird): a review and some new data. Heredity 40: 269-280.

Muggleton J., Lonsdale D. \& Benham B.R. 1975: Melanism in Adalia bipunctata L. (Col.: Coccinellidae) and its relationship to atmospheric pollution. J. Appl. Ecol. 12: 451-464.

Ongagna P., Giuge L., Iperti G. \& Ferran A. 1993: Cycle de développement d'Harmonia axyridis Pallas (Col.: Coccinelli- dae) dans son aire d'introduction: Le sud-est de la France. Entomophaga 38: 125-128.

OSAWA N. \& NishidA T. 1992: Seasonal variation in elytral colour polymorphism in Harmonia axyridis (the ladybird beetle): the role of non-random mating. Heredity $69: 297-307$.

RickLefs R.E. 1990: Ecology. 3rd edition. W.H. Freeman and Company. New York. 896 pp.

Schanderl H., Ferran A., Coderre D., Ventura A., Soares A.O., Almeida J.M.P. \& Taveira J. 1991: Capacidade de dispersão de Harmonia axyridis Pallas (Col: Coccinellidae) após uma largada inundativa para controlo de afídeos do milho Rhopalosiphum padi L. e Sitobion avenae F. (Hom.: Aphididae). Relatórios e Comunicações do Departamento de Biologia, Universidade dos Açores 20: 59-64.

SCHANDERL H.J.C. \& AlmeIDA J.M.P. 1992: Introdução de Harmonia axyridis Pallas (Col., Coccinellidae) na Ilha de S. Maria. Açoreana 7: 401-406.

Stewart L.A. \& Dixon A.F.G. 1989: Why big species of ladybird beetles are not melanic? Funct. Ecol. 3: 165-177.

SteWARt L.A., Dixon A.F.G., RƯŽIČKa Z. \& IPERTI I. 1991a: Clutch and egg size in ladybird beetles. Entomophaga. 36: 329-333.

Stewart L.A., Hemptinne J.-L. \& Dixon A.F.G. 1991b: Reproductive tactics of ladybird beetles: relationships between egg size, ovariole number and developmental time. Funct. Ecol. 5: 380-385.

TAN C.C. 1946: Mosaic dominance in the inheritance of color patterns in the lady-bird beetle, Harmonia axyridis. Genetics 31:195-210.

TAN C.C. 1949: Seasonal variations of color patterns in Harmonia axyridis. Proc. 8th Intern. Congr. Genet. 669-670.

Tedders W.L. \& Schaefer P.W. 1994: Release and establishment of Harmonia axyridis (Coleoptera: Coccinellidae) in the southeastern United States. Entomol. News 105: 228-243.

WAAGE J.K. \& Mills N.J. 1992: Biological control. In Crawley, M. J. (ed.): Natural Enemies. Blackwell Scientific Publ. London, pp. 412-430.

Willmer P.G. \& UNwIN D.M. 1981: Field analysis of insect heat budget: reflectance, size and heating rates. Oecologia 50: 250-255.

WRIGHT E.J. \& LAING J.E. 1978: The effects of temperature on development, adult longevity and fecundity of Coleomegilla maculata lengi and its parasite Perilitus coccinellae. Proc. Entomol. Soc. Ontario 109: 33-48.

Received April 18, 2000; revised June 12, 2001; accepted July 30, 2001 